\title{
Thinking on Using New Media Technology in Ideological and Political Teaching in Colleges and Universities
}

\begin{abstract}
Xiaoling $\mathrm{Wu}^{1}$
${ }^{I}$ Fuzhou Preschool Education College, Fuzhou, Jiangxi,344000

739960103@qq.com

ABSTRACT

The teaching practice in the new era requires the teachers of Ideological and political course to transform their roles in the teaching process, to make the students become the directors of the classroom, and to really return the classroom to the students. Under the call of this requirement, the development of new media technology not only gives impetus to the development of Ideological and political education, but also brings development problems. In the new era, it is an unavoidable problem for colleges and universities to grasp the development and application of new media technology, promote the innovation and change of teaching mode, complete teaching courses, create a team of teachers with complementary advantages, and improve the harvest of college students in the ideological and political classroom.
\end{abstract}

Keywords: new media technology, college Ideological and political course, teaching practice

\section{在高校思政课教学中运用新媒体技术的思考}

\author{
伍小玲 1
}

\section{${ }^{1}$ 抚州幼儿师范高等专科学校 江西 抚州 344000 \\ 739960103@qq.com}

\section{摘要:}

新时代教学实践要求思政课教师在思政课教学过程中进行角色转化, 要让学生成为课堂的主任, 做到把课堂真 正还给学生。在这一要求的号召呼吁下, 新媒体技术的发展给思政课教学发展的动力同时也带来了发展的难 题。新时代下高校如何把握新媒体技术开发运用, 推动教学模式的创新改变, 完整的教学课程, 打造优势互补 的教师团队，提高大学生在思政课堂的收获是无法回避的难题。

关键词: 新媒体技术; 高校思政课; 教学实践

\section{1.引言}

新媒体教学的技术特征主要表现为传播性以及 互动性, 这对于传统的教学方式方法存在很多方面的 大变革。这一变革为高校在思政课教学课堂带来了便 利性的物质条件, 同时也引发了思政课教育教学才能 更好契合实际的思考。如何上好思政课，使得高校的 思政课如何满足新时代要求, 打造高质量高品质的思 政课, 是高校思政教育必须要进行研修的课题。

\section{2.国内关于新媒体技术开发运用的实践}

1986年中国国内新媒体技术方兴未艾, 直至 2006
年之后, 新媒体技术被我国映入并在我国生根发芽, 以较快的速度发展。相对于传统媒体而言, 新媒体具 有报纸、电视、广播等传统形式所不具备的特殊之处。 “新媒体的优势集中开放、互动、多元的传播模式, 相 较于传统媒体在传播信息是封闭、单一的特点, 新媒 体在大众传播模式上独领风骚。传统媒体在教育实践 中正逐渐让位于新媒体。不单单是在教育实践层面, 新媒体早已经渗透到人们的社会生活、工作实践等方 维度, 新媒体已经悄无声息成了现代的生活必需品。 现在, 人们已经开始关注新媒体传播信息的效率和质 量, 试图寻找新时代新媒体传播的途径和方法 ${ }^{[6]}$ 。在 此次新冠疫情全国停课的现实情况下，新媒体的作用 在这一平台得以发挥。在新媒体的作用下，慕课、腾 
讯狐疑等相关平台的开发、运用和推广，手机上课、 直播教学等各式各样的互联网技术解决了教育停滞 的难题。真正让广大学子做到了“听课不停学”这一变 化引发了我国思政课教学从教学理念、教学模式的思 考、在新课改权方位改革的背景下，目前，我国应该 以新媒体技术开发运用为依托建立微课、翻转课堂、 网络直播教学的多元化教学模式。

相较于传统的媒体而言, 新媒体在教学方式、教 学模式上优势明显, 21 世纪是信息时代, 身处在 21 世纪的莘莘学子早已离不开它, 同时作为教育 21 世 纪大学生的思政课教师无法回避新媒体带来的改革。 但是现实的困境主要集中在新媒体在实施的过程中 覆盖率并不理想, 追本溯源, 笔者认为主要有以下三 个方面的原因: 课堂教学仍然以教师为中心、学生主 体地位的确立关注不足;目前的教学现状主要是线下 讲授, 线上线下课堂衔接不畅;教师团队配合不力, 新 媒体普及力度不够。要实现新媒体的广泛运用于思政 课堂的现实需要, 从而借助新媒体技术改革课堂教学, 创新教学模式, 推动校园文化革新仍需要不断努力。

\section{3.改革课堂教学:复原学生的主体地位}

理论界就课堂应以”教师为中心“还是”学生为中 心“进行了不同程度的争论。以”教师为中心“还是”以 学生为中心“并不仅仅是一个理论性的问题, 同时也 是具有实践意义, 以何种模式为中心决定了教师如何 组织课堂教学形式, 是否进行课堂翻转。

中国自古以来的传统教学的班级授课制始终强 调的都是“教师、教室、课本”三中心展开的。自班级 授课制产生伊始, 教师成为了知识的先知者, 学生对 于知识是处于未知后知的状态。教师在有限的资源内 依据课本和有关教材进行备课, 老师通过讲授的方式 将知识传播给学生, 学生在课堂里跟随老师的步伐被 动地接受知识的传授。随着素质教育理念的提出, 传 统的“填鸭式”教学的不足逐渐被实践中的教师意识 到, 广大教师意识到这一教育模式对于学生独立思考 能力的扼杀性, 因而在教学实践中不约而同普遍地选 用“启发式”教学。传统的教育方式主要表现为: 以教 师的“教”为中心, 只不过较注重激发学生的学习兴趣, 把教材内容填鸭灌输给学生。老师在这一模式中的作 用更像是灌输者, 但是这种教育模式虽然存在很多不 足, 但是其也有可取之处, 传统的教学方式更有利于 保护思政课教学的政治性、科学性和思想性, 但是传 统思政教育的缺点也是显而易见的, 传统的思政教育 课堂里忽视了学生的个性和主体地位, 学生只是机械 的学习知识, 并没有将知识转化为实践的能力。知识 的实践性的缺乏会使得把学生独立思考能力的缺乏。

以“网课”为例, 在新媒体技术的作用下, 网课这 一形式的教学模式率先进军教育领域。不仅仅是网课, 还包括慕课、直播课等不同形式的课程。“慕课”是“随 着多媒体和网络技术的日益普及、媒介型大学的在线 教育课程的大量涌现, 才逐渐发展起来的一种新型课
堂教学结构形态” [7]。这种新型的课堂, 以建构主义 学习理论和学习环境作为理论基础, 教师角色发生转 变, 由知识的传授者转变为学生学习的建构者, 充分 发挥学生在学习过程中的主动性和积极性。慕课和网 课这一教学模式的研发以及应用, 使得教师与学生的 角色进行了转换, 相对于传统教育实践, 这一新形式 的教育模式更符合翻转课堂的时间按行要求, 真正做 到了角色的转换。以互联网慕课为例, 学生在登陆注 册后可以自主进行选课, 根据自己的需要以及自己的 学习兴趣进行不同程度的学习, 就学生在学习过程中 的各种疑难问题, 平台也设计了, 有问题在线提问教 师在后台及时解答的制度。因此, 在“慕课”的“课堂” 上, 学生在彼此交流对知识的认识和理解中, 获取知 识, 教师由传统意义上的知识“权威”变成了新型学习 者的“导师” [9]。

事情的发展总是像一把双刃剑, 就慕课制度而言, 目前在教育实践中主要存在的问题是翻转课堂的程 度超出预期。在教学实践中部分思政课教学老师并未 完全适应这一教学形式, 实践中存在教师在这一教学 过程中完全放弃管理, 任由学生自由学习, 加之学生 自主学习能力不足, 对于互联网世界形成理性的认识, 很容易将人为灌输知识变为新型的互联网灌输。因此, 在这一现实窘况之下, 广大思政课教师如何利用新媒 体资源, 融合新媒体与思政教育成为了新的需要研修 的课题。如何让学生在互联网海量的信息世界中选择 正确有效的信息进行学习, 真正做到凸显学生的主体 地位, 广大高校思政老师需要切实关注学生的成长轨 迹, 从培育学生正确的三观角度出发, 学习创新不断 进步。

\section{4.创新教学模式:展开完整的教学过程}

传统课堂已经无法满足于现阶段高质量多媒体 化的教育教学, 翻转课堂、智慧课堂、云课堂等概念 的提出使得教育工作者必须要正视思政教育所面临 全所未有的变革, 思政教师必须与时代接轨, 才能更 好的完成教育教学工作。

当前正处在创痛教育与新媒体教育交接的关键 时期, 高校的思政教育一是思政课在发展过程中主要 面临几大难题，笔者总结为三点: 高校的课程安排无 法完全给予思政老师足够的时间进行安排新给教学, 现阶段思政老师更多面临的是如何将课程讲授完毕, 学生在课堂上学了之后课下再学, 由此导致恶性循环, 导致的结果是学生仍然是被动重复学习, 加大学生学 习负担; 思政教育体系庞大内容较多、教师在完成基 本课堂教育的同时开设电子平台的课程, 容易使得老 师花费太多精力, 甚至会使得老师疲于应对繁重的备 课工作，思政老师不仅课堂教学还要不时操作“高科 技”, 由此导致的后果四教师建设在线开放课程是并 不用心经营, 在课程建好后导致课程闲置造成浪费, 亦或是给学生布置“政治”任务, 强迫学习效果不佳; 电子平台上的教学更多依靠学生自主性, 学生在电子 平台上的自主性是变量因素, 学生自律水平参差不齐, 
状况捉摸不定。思政老师在运用新媒体技术同时，教 师无法把控学生和课堂, 没有能够即使了解掌握学生 情况。由此可能出现的状况是强迫进行回答与反馈, 平台反应出来的学生信息真实性存疑, 信息参考价值 不大。

笔者认为针对以上问题, 破解之法主要应当对症 下药:在思政教师层面, 思政老师若想将思政教育以及 新媒体技术完美结合, 就必须顺应时代潮流, 从学生 角度出发, 思索考虑新媒体技术的运用如何大道更好 的教学效果;另一方面, 从学生方面, 强化自身自律意 识, 在平台是学习应科学学习的方法, 正视互联网教 学, 做到线上线下无差别化学习, 从教育科研工作者 方面: 为提高思政教育质量, 应当在课程开发、课程 设计、平台管理新的切合时间的探索与开发, 以此来 提高思政课的质量, 为发挥思政教育在学生思想领域 的重要作用而不断努力、锐意创新。

\section{5.转变教师角色:打造互补的教学团队}

云端教学最大的特色在于云端教学的流程中强 调师生角色的转化, 在云端的课堂上不在类似于传统 课堂那般, 教师在课堂以教材为中心进行灌输式的教 育, 云端课堂的可贵之处在于准中学生的自主创造性, 电子平台的储存量大的特点使得云端课堂学习资料 浩瀚如烟, 丰富的教学资源为学生在云端学习提供了 便利条件, 同时云端便利的互动交流平台可以让学生 可以在云端进行完成作业、提出疑问等必要的教学流 程。流畅、生动的教学, 需要强大的现代教育技术手 段的支撑, 除了主讲教师外, 辅导教师和助教的配备 也成了刚需。“慕课”时代需要教师有个人魅力, 但是, 教学团队的整体实力更显重要 $[10]$ 。借助新媒体进行 思政教育是高校思政教师在这个新时代进行知识传 播所不可或缺的条件, 思政教育与新媒体的融合也是 新时代教育工作者的荣膺。

新时代情况下师资力量有限, 教育资源紧缺的现 状使得思政教育在发展的过程中必须要进行精诚合 作, 新媒体背景中的思政教育需要新媒体课程建设团 队和教师教学团队通力合作, 新媒体课程建设研发团 队在研发的同时需要了解一线老师他们最需要的诉 求, 带领老师进行功能开发以及软件设计, 双方合作 实现团队共享, 这样可以让教师团队的教学活动中可 以直接接轨时代科技变化, 消除教师与科技隔膜。

另一方面, 对于思政教育工作者而言在具体实施 教育实践的环节, 在课程压力了较大的情况下, 在现 有的师资力量普遍薄弱的状况下, 建议高校的思政老 师可以尽早选拔优秀的研究生助教团, 助教团共同合 作完成教学工作, 可以让助教团队参与教学各环节, 比如备课、答疑、作业批改、课堂管理、课后辅导及 网络技术支持等, 并及时为主讲教师整理相关数据。 并且助教老师往往对于新技术的把握程度更为成熟, 可以更好的帮助教师进行教育工作。

\section{6. 结论:}

新媒体技术的应用于高校思政课目前仍然处于 方兴未艾的阶段, 新媒体技术的运营尚且无法面面俱 到。但是发展的过程是曲折的, 前途是光明的, 相信 在不久的将来更为先进的技术手段的出现以及教育 师资普遍水平的提高可以使得系内提运用的难题逐 一得到解决。现阶段的任务主要是思考当前新媒体技 术运用到现阶段思政教学实践中存在的若干问题, 并 加以及时解决。同时教育工作者与科研团队应该科学 把握思政课教学规律, 进行思政教育工作的锐意创新, 为高校学子的思政教育添砖加瓦, 更好的完成对于高 素质人才立德树人的目标。

\section{REFERENCES}

[1] Liang Congrong, the way to improve the effectiveness of the rule of law education in Ideological and political education in Colleges and universities in the media era $[\mathrm{J}]$. Chinese Journal of multimedia and network teaching (Electronic Edition), 2019,0 (4S): 170-171

[2] Liu Xiaojuan. The way to improve the effectiveness of the rule of law education of Ideological and political course in Colleges and universities in the era of financial media []. Journal of Fuyang Normal University: Social Science Edition, 2017,0 (3): 148-151

[3] Xiao Gaohua, Zhou Meng. Integrating the excellent culture of rule of etiquette into the education of rule of Law -- a discussion on the cultivation of College Students' concept of rule of law in the teaching of Ideological and Political Education [J]. Journal of Kaili University, 2016,34 (1): 15-18

[4] Yang Xinying, Li Junsong, Yan Wen. Deconstruction and reconstruction of Ideological and political theory course in Colleges and Universities under the background of "new media" [J]. Heilongjiang Education: higher education research and evaluation, 2018,0 (10): 32-35

[5] Tang Chunlan. Practice of Ideological and political education reform in Application-oriented Colleges and universities from the perspective of MOOC -- Taking "basic" course in Lushan College of Guangxi University of science and technology as an example [J]. Intelligence, 2017,0 (25): 186-187

[6] Yang Xinying, Li Junsong, Yan Wen. Deconstruction and reconstruction of Ideological and political theory course in Colleges and Universities under the background of "new media" $[\mathrm{J}]$. Heilongjiang Education: higher 
education research and evaluation, 2018,0 (10): $32-35$

[7] Yang Zhendong, Hao Xiaofei, Ma Jing. Innovation path of network ideological and political work in Colleges and Universities under the media environment $[\mathrm{J}]$. Journal of Social Sciences of Shanxi University, 2019,31 (S01): 34-38

[8] Huang Ni. Empirical research on College Students' online public opinion in the new media environment -- Based on the investigation and analysis of some universities in Xi'an [J]. Social scientist, 2014 (3): 44-49

[9] Zhang Xinzhu. Practical exploration on the role of student party members in Colleges and universities in the new era -- a case study of Party Construction in student apartments of Xi'an University of Posts and Telecommunications [J]. Yangtze River series, 2017,0 (32): 234-234

[10] Yang Jie, Chen Shenhong. Cultivation of Marxist Belief: the purpose and path of Ideological and political education in Colleges and Universities -from the perspective of new media era [J]. Journal of Guangdong Institute of socialism, 2019,0 (3): 104-107

[11] Han Yuxia. Exploration and practice of informatization teaching mode of Ideological and political course in Colleges and universities in the new media era [J]. Chinese Journal of multimedia and network teaching (Electronic Edition), 2019,0 (8Z): 145-146

[12] Li Chunli. Discourse Dilemma Analysis of College Students' Ideological and political education from the perspective of new media [J]. Journal of Jiangxi Electric Power Vocational and technical college, 2018,31 (6): 121-122

[13] Du Lingfei. The intention investigation and construction ideas of using new media to carry out ideological and political education in Colleges and universities [J]. Journal of Hebei young management cadre college, 2019,31 (3): 57-62

[14] Li Kun, Li Guifeng. The situation and optimization of Ideological and political education of College Students under the condition of new media -- Based on the investigation and analysis of some universities in Tangshan [J]. Reform and opening up, 2020 (7): 65-68

[15] He Yanhui, Zhong Yang. Analysis on the practice of "micro education" for college student party members -- Taking the "Secretary project" of the general Party branch of Mathematics Department of Guangdong Second Normal University as an example [J]. Shanxi youth, 2018,0 (18): 178-178 